\title{
A VALIDITY AND RELIABILITY STUDY OF THE TURKISH VERSION OF THE AMBIVALENT AGEISM SCALE
}

Turkish Journal of Geriatrics

DOI: 10.31086/tigeri.2020.192

2020; 23(4): 534-545

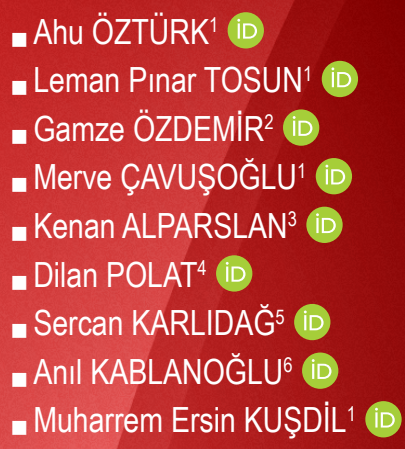

CORRESPONDANCE

${ }^{1}$ Muharrem Ersin KUŞDiL

Bursa Uludağ University, Faculty of Arts \&

Sciences, Department of Psychology, Bursa, Turkey

Phone: +902242941871

e-mail: mekusdil@uludag.edu.tr

Received: Jul 31, 2020

Accepted: Dec 06, 2020

Bursa Uludağ University, Faculty of Arts \&

Sciences, Department of Psychology, Bursa, Turkey

${ }^{2}$ Çanakkale Onsekiz Mart University, Faculty of Arts \& Science, Department of Psychology, Çanakkale, Turkey

${ }^{3}$ Muş Alparslan University, Faculty of Arts \& Science, Department of Psychology, Muş, Turkey

${ }^{4}$ Bartın University, Faculty of Literature, Department of Psychology, Bartın, Turkey

${ }^{5}$ Altınbaş University, School of Economics, Administrative and Social Sciences, Department of Psychology, İstanbul, Turkey

${ }^{6}$ Süleyman Demirel University, Faculty of Arts \& Sciences, Department of Psychology, Isparta, Turkey

\section{A}

Introduction: This study aimed to assess the psychometric properties of the Turkish version of the Ambivalent Ageism Scale, which measures 2 forms of ageism, namely benevolent and hostile ageism.

Materials and Methods: Data were collected from 222 adults through an online survey. Participants completed Turkish versions of the 13-item Ambivalent Ageism Scale and the Implicit Association Test adapted for ageism. Construct validity was assessed through confirmatory factor analyses. Internal consistency and split-half consistency were also calculated. Criterion validity was assessed by correlating ambivalent ageism and its subscales with implicit ageism scores.

Results: The results of confirmatory factor analysis of 12-items confirmed the original structure by exhibiting a good fit to the data (goodness of fit index $=0.93, p$ $<.001$, comparative fit index $=0.97$, and root mean square error of approximation $=$ 0.07). Internal consistency of the Ambivalent Ageism Scale and its 2 subscales were found to be satisfactory, with Cronbach's alpha being .89 for benevolent ageism (9 items), .79 for hostile ageism ( 3 items), and .89 for the total scale. Scale had a high split-half reliability coefficient (0.95). Implicit ageism positively correlated with ambivalent ageism (total score) and both benevolent ageism and hostile ageism $(.22, .21$, and .16, respectively). Except for cognitive assistance/protection, which was a sub-factor of benevolent ageism, no age and gender difference was found in any of the ageism scores.

Conclusion: It was decided that the Turkish version of the Ambivalent Ageism Scale is a valid and reliable measure of negative attitudes toward older adults.

Keywords: Ageism; Prejudice; Attitude; Reproducibility of Results 


\section{INTRODUCTION}

Despite the increase in their lifespan in most countries of the world, including Turkey $(1,2)$, older adults continue to be viewed in a negative light; both in social life (3) and scientific literature (4) older adulthood is viewed as if it is associated with sickness, physical/mental deterioration, and closeness to death. This stereotyping, which ignores the substantial variation in several characteristics in aged individuals, ranging from physical condition to mental competencies, is called "ageism" (5). Ageism has not attracted as much attention as sexism and racism among researchers, and its existence and effects have not been made fully visible (6). Ageism is not always "hostile" and does not always cause "active harm." Ageism can also include "protectionist" behaviors, including "active facilitatory behaviors" (e.g., excessive/unwanted help) and "passive harm" (e.g., social exclusion) $(7,8)$. The first is referred to as "hostile ageism" (HA) and can be explained as antipathy toward older adults $(6,9)$. The latter is referred to as "benevolent ageism" (BA), and is characterized by patronizing behaviors (7, 9). Because the protective attitudes and behaviors are evaluated positively by most individuals, it can be more difficult to address the benevolent forms of ageism and their negative consequences $(7,10)$. Therefore, drawing exclusively upon the literature on sexism, Carry, Chasteen and Remedios differentiated the protective form from the hostile and named this as "ambivalent ageism" (AA), by combining benevolent and hostile prejudices. AA is assumed to arise out of the co-presence of both hostile and benevolent prejudices, similar to ambivalent sexism (7).

Carry, Chasteen, and Remedios have recently developed a 13-item Ambivalent Ageism Scale (AAS) in two studies and demonstrated that the scale had a two-factor structure (HA and BA) $(7,10)$. In the first study, HA predicted belief that older adults were cold and incompetent, whereas BA predicted evaluations of older adults as warm. It was also found that participants with high BA but low HA were likely to view older adults as warm and less competent, confirming the idea that, similar to sexism, there are two forms of ageism, and that AAS is successful in measuring these elusive forms independently. Other studies that have used the AAS have demonstrated a positive correlation between employees' AA scores (total score for 13 items) and their attitudes toward the employment of older adults. Furthermore, AA has been found to be higher in youth and women, but has not been found to be related to educational level (11). In addition, BA has been observed to lead to a perception of behaviors toward older adults as just, even if they are not (10). In a recent study in Turkey, AA was found to be related to social identity motivations and predicted by belonging to a young group (12). One of the findings of a study using the visual screening task showed that adult participants (aged between 19 to 27) devoted less time for looking at older faces than the younger ones, implying that ageism may also have a physiological basis (13).

Another explanation regarding the elusive nature of ageism suggests that ageism is an "implicit attitude" (14). The measures of AA that are currently used in most prejudice research are generally based on self-reports and evaluate prejudices as "explicit attitudes" resulting from conscious, intentional, and controllable cognitive processes. "Implicit" attitude measures capture uncontrolled automatic cognitive processes (15). The most important advantage of an implicit measure is that, by limiting the participant's control over his/her responses, they produce results that are relatively free from social desirability and impression management strategies $(16,17)$. The Implicit Association Test (IAT) is the most commonly used instrument for measuring prejudice against groups such as people of African descent, women, and older adults (16). Past studies on ageism generally agree that young people are evaluated very positively, whereas older adults are perceived more negatively (18). In an online study of 70,000 people of various ages, it was found that implicit ageist attitudes, including those of older adults themselves, 
were among the most common of all prejudiced attitudes and were much higher in magnitude than explicit ageist attitudes (14).

Current research on ageism in Turkey is predominantly based on explicit attitude scales that measure hostile ageist attitudes toward older adults. Although the prevalence of positive attitudes toward older adults is quite high (19), findings showing that even medical students do not prefer to work in geriatric clinics (20) and that nurses experience difficulties communicating with older adult patients (21) indicate that ageist attitudes cannot be fully captured with explicit attitude scales that focus primarily on the hostile form of ageism. More sophisticated instruments such as the AAS are needed to prevent the negative social and psychological consequences of ageism.

The aims of this study were as follows: (a) to assess the validity and reliability of the Turkish version of the AAS and (b) to cross-validate the AAS and its $H A$ and BA subscales, using a recently developed implicit measure, namely the IAT.

\section{MATERIALS AND METHODS}

\section{Study Sample and Procedure}

Data from the present study were collected as part of a larger study in which ageism was examined in the context of the coronavirus disease pandemic. The sample consisted of 226 individuals who were snowball-sampled using an online survey tool (Survey Monkey, SVMK Inc., San Mateo, CA, USA) between April and May 2020 in Turkey. After excluding two participants who did not complete the IAT and two others whose error rates and/or durations of response were above the acceptable limit, the final sample included 222 adults (142 women, 80 men; $\overline{\mathrm{x}}_{\text {age }}=32.93$ years, standard deviation $[S D]=11.64$ ). No age difference was found between women $(\overline{\mathrm{x}}=$ $31.84, \mathrm{SD}=11.38)$ and men $(\overline{\mathrm{x}}=34.87, \mathrm{SD}=11.90)$, $\mathrm{t}_{(220)}=-.1 .87, \mathrm{p}>$.05). All participants completed the IAT (16) adapted for ageism, AAS (7), and sociodemographic questions, along with other scales that were used for other purposes in the online survey form. Participants were not compensated in any form for their participation.

\section{Measures}

The AAS. The AAS was developed by Cary et al. (7) and consists of nine items on BA and four items on HA. Their study revealed that it is possible to consider BA factor as having two sub-factors: Cognitive assistance/protection (CA/P) and unwanted help (UH). Responses for each item are based on a 7 -point Likert scale $(1=$ Strongly Disagree; 7 = Strongly Agree). The original study reported internal reliability for the BA and HA subscales as $\alpha=.89$ and $\alpha=.84$, respectively, and the subscales were found to be highly correlated with each other $(r=$ $.62, p<.001)$. The entire scale also had good internal consistency $(\alpha=.91)$. Test-retest reliability was good for both subscales and the entire scale $(r=.76$ and .80, respectively). Turkish and English items are given in Appendix A and Appendix B, respectively.

The IAT. The IAT was developed by Greenwald $(15,16)$ to measure implicit prejudice, and for this study participants completed an online version of the IAT for ageism (Inquisit, Millisecond Software, Seattle, WA, USA). The IAT requires the participant to respond as quickly and accurately as possible to seven blocks of stimuli (compatible and incompatible blocks), each consisting of 20 to 40 trials. During these trials, participants were asked to perform a categorization task, in which they sorted pleasant/ unpleasant words and photographs of the faces of older/younger individuals (Figure 1). Target words and photographs appeared in the center of the screen, whereas categories are placed on either the left or right top corners. To assign items to the left category, participants pressed the " $e$ " key, and for the right category, they pressed the " $p$ " key. In the present study, the original test photographs of old and young faces and the Turkish versions of the pleasant and unpleasant words were used (for samples of the content, see Figure 1). The IAT produces a $d$ score for the extent of the implicit association that ranges between 2 and -2 . The $d$ score indi- 
Figure 1. Sample screenshots of the IAT, information about the trials, and examples of the words used.
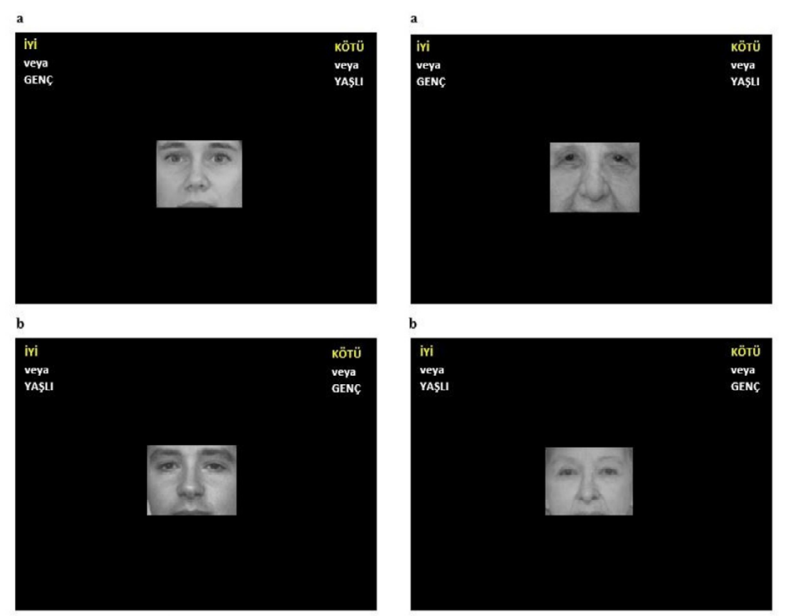

\begin{tabular}{|c|c|c|c|c|c|}
\hline \multirow{2}{*}{ Block } & \multirow{2}{*}{$\begin{array}{c}\text { Number of } \\
\text { trials }\end{array}$} & Phases & \multirow{2}{*}{$\begin{array}{c}\text { Discrimination } \\
\text { Task }\end{array}$} & \multicolumn{2}{|c|}{ Key Items } \\
\cline { 5 - 6 } & & & Left ('E') & Right ('P') \\
\hline 1 & 20 & $\mathrm{P}$ & Face & Young & Old \\
\hline 2 & 20 & $\mathrm{P}$ & Word & Pleasant $^{\mathrm{d}}$ & Unpleasant $^{\mathrm{e}}$ \\
\hline 3 & 20 & $\mathrm{C}$ & Word + Face & Pleasant +Young & Unpleasant + Old \\
\hline 4 & 40 & $\mathrm{C}$ & Word + Face & Pleasant + Young & Unpleasant + Old \\
\hline 5 & 20 & $\mathrm{P}$ & $\begin{array}{c}\text { New keys } \\
\text { (switched) }\end{array}$ & Old & Young \\
\hline 6 & 20 & $\mathrm{C}$ & Word + Face & Pleasant + Old & Unpleasant + Young \\
\hline 7 & 40 & $\mathrm{C}$ & Word + Face & Pleasant + Old & Unpleasant + Young \\
\hline
\end{tabular}

Note. Adapted from Inquist Millisecond Software,

https://www.millisecond.com/download/library/v5/iat/ageiat/ageiat.web

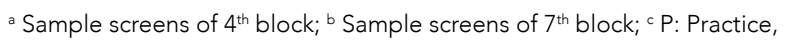

C: Critical; d Joy (Neşe), Wonderful (Harika), Pleasure (Memnuniyet); e

Agony (Izdırap), Terrible (Berbat), Awful (İğrenç)

cates the strength of associations (no association: $0- \pm 0.15$; low: $\pm 0.15- \pm 0.35$; moderate: $\pm 0.35- \pm 0.65$; high $\pm 0.65- \pm 2$ ). A positive score indicates that the participant tends to pair negative attributes more with older adults than with members of younger age groups, and a negative score indicates that the participant tends to pair positive attributes more with older adults than with members of younger age groups.

The IAT has been previously employed in Turkey by some studies using stimuli related to Turkish words $(22,23)$ and Turkish and Kurdish names
(24). Şenyurt, Coşkun and Ünlü has reported that, although it depended on a different computational procedure, an open source Turkish IAT version that they developed had satisfactory psychometric qualities (25). Analyses of the data derived from the IAT in the present study showed that response times for compatible and incompatible blocks had good reliabilities (Cronbach alphas were .90 for each of the first and second compatible blocks; .86 for the first incompatible block and .94 for the second incompatible block).

Sociodemographic questions. The sociodemographic questions form included questions on age, gender, marital status, occupation, place of residence, education, and monthly income.

\section{Translation of AAS Items and IAT Words}

The words used in the IAT were translated to Turkish by two members of the research team who were native Turkish speakers and competent in English. The AAS items were translated by the same members of the research team and the final form was examined by another member to check for possible inconsistencies.

\section{Data Analysis}

All analyses were performed using SPSS version 23 (IBM Corp., Armonk, NY, USA) and AMOS (IBM Corp.). Construct validity was assessed through and confirmatory factor analyses. Cronbach alpha coefficients and the split-half reliability analysis were used for assessing the internal consistency. Assessment of criterion validity was done by correlating scores for AA and its subscales with IAT scores. Age and gender differences were examined by t-tests.

\section{Ethical Issues}

This study was approved by the Ethics Committee of Bursa Uludag University on July $27^{\text {th }}, 2020$ (reference number: 2020-05). All participants completed questionnaires anonymously after providing their consent online. 
Table 1. Sociodemographic characteristics of the sample $(\mathrm{N}=222)$

\begin{tabular}{|c|c|c|}
\hline Variable & Frequency & $\%$ \\
\hline \multicolumn{3}{|l|}{ Gender } \\
\hline Women & 142 & 64 \\
\hline Men & 80 & 36 \\
\hline \multicolumn{3}{|l|}{ Age } \\
\hline $19-30$ years & 119 & 53.6 \\
\hline $31-69$ years & 103 & 46.4 \\
\hline \multicolumn{3}{|l|}{ Marital status } \\
\hline Single (unmarried, divorced, or widowed) & 141 & 63.6 \\
\hline Married & 81 & 36.4 \\
\hline \multicolumn{3}{|l|}{ Education } \\
\hline High school or below & 96 & 43.2 \\
\hline College & 78 & 35.1 \\
\hline Graduate school & 48 & 21.7 \\
\hline \multicolumn{3}{|l|}{ Occupation } \\
\hline Student & 76 & 34.2 \\
\hline Blue-collar work & 18 & 8.1 \\
\hline White-collar work & 76 & 34 \\
\hline Self-employment & 15 & 6.9 \\
\hline Not working (unemployed, retired, or homemaker) & 37 & 16.8 \\
\hline \multicolumn{3}{|l|}{ Living with a person who is over 65 years of age } \\
\hline Yes & 25 & 11.3 \\
\hline No & 197 & 88.7 \\
\hline \multicolumn{3}{|l|}{ Residence } \\
\hline Rural or small town & 36 & 16.2 \\
\hline Small city & 38 & 17.1 \\
\hline Large city & 148 & 66.7 \\
\hline \multicolumn{3}{|l|}{ Income (monthly) } \\
\hline Below $4000 €$ & 61 & 27.5 \\
\hline 4000-7000€ & 75 & 33.8 \\
\hline Above 7000 モ & 86 & 38.7 \\
\hline
\end{tabular}




\section{RESULTS}

Analysis of the sociodemographic characteristics of the sample revealed that the majority of the participants (64\%) were women, single (64\%), and had a high level of education (57\%). Approximately 50\% of the participants were actively employed. In addition, more than $75 \%$ of respondents resided in urban areas, and less than $12 \%$ were living with a relative aged 65 years or over (Table 1).

\section{Construct Validity Analyses}

First, exploratory factor analyses with two-factor and three-factor solutions were run independently using varimax and direct oblimin rotations. According the result of the analysis with the two-factor solution, one item (item \#1) was need to be removed because it was loaded on both factors. On the other hand, according to the analysis with the three-factor solution, two items (items \#1 and \#13) were needed to be removed as they were loaded on multiple factors. Cary et al (7) suggested AAS neither being a two-factor nor three-factor scale. Rather, they suggested that it is a scale with higher order structure involving two factors (BA and $\mathrm{HA}$ ), and one of those factors (BA) combining two sub-factors. The first one of BA sub-factors was composed of items measuring to what extent people agree that older adults need cognitive assistance/protection (CA/P), and the second one contained items measuring the agreement with the idea that older adults should be offered unwanted help (UH). In the current study, a higher order confirmatory factor analysis was conducted on 13 items to test Cary et al's (7) findings on AAS's higher order structure.

The cutoff values of a good fit for these indices were selected as $>0.90$ for the comparative fit index $<0.08$ for the root mean square error of approximation, and $<2.0$ for the ratio of $\chi 2$ to degrees of freedom $(\chi 2 / d f)$. The $\chi 2 / d f$ ratio was preferred because $\chi 2$ statistics are known to be sensitive to sample size.

One item ("Old people are a drain on the health care system and the economy") was removed as it had a poor loading. In addition, four covariances (between the error terms of items 2 and 3, items 4 and 7, items 5 and 6 and items 8 and 9; see Figure 2) were added to the model as suggested by modification indices. The model was then re-tested. Factor loadings for this scale ranged between .62-.72 for UH sub-factor of BA, between .53-.73 for CA/P sub-factor of BA and between .66-.82 for HA (Figure 2). The scale with this higher-order structure had a good fit to the data $(\chi 2=97.40, \chi 2 / \mathrm{df}=1.99$, goodness of fit index $=.93$, comparative fit index $=.97$, root mean square error of approximation $=$ .07 , and standardized root mean squared error $=$ .04). Construct Reliability (CR) scores for main and sub-factors were all acceptable (.68 for CA/P; .82 for $\mathrm{UH} ; .87$ for BA and .79 for HA).

\section{Reliability and Correlation Analyses}

Cronbach's $\alpha$ coefficients with corrected total item correlations and item-total correlations were used to asses internal consistency. Corrected item totals for the entire scale ranged between .49 and .69. The reliability of both BA and HA was satisfactory, with Cronbach's $\alpha$ being .88 for the 9-item BA subscale, .79 for the 3 -item HA subscale, and .89 for the entire scale. If any of the items were deleted, Cronbach's $\alpha$ for the entire scale varied between .87 and .89, showing that there was no need to discard any items. Cronbach's $\alpha$ for the two sub-factors of BA were $.78(\mathrm{CA} / \mathrm{P})$ and $.86(\mathrm{UH})$. The split-half reliability for the two halves (even versus odd numbered items) of the scale was found to be satisfactory (.94).

Pearson correlations were calculated to examine the interrelations between the factors (Table 2). As in the original study, BA and HA were found to be positively correlated, $r=.57, \mathrm{p}<.001$, two tailed.

\section{Criterion Validity}

Implicit ageism (IA), which was selected as a criterion for testing the validity of the AAS, was found to be positively correlated with AA (total score) and its subscales (Table 2). The correlation coefficient 
Figure 2. Results of the confirmatory factor analysis of the 12-item Turkish version of the AAS.

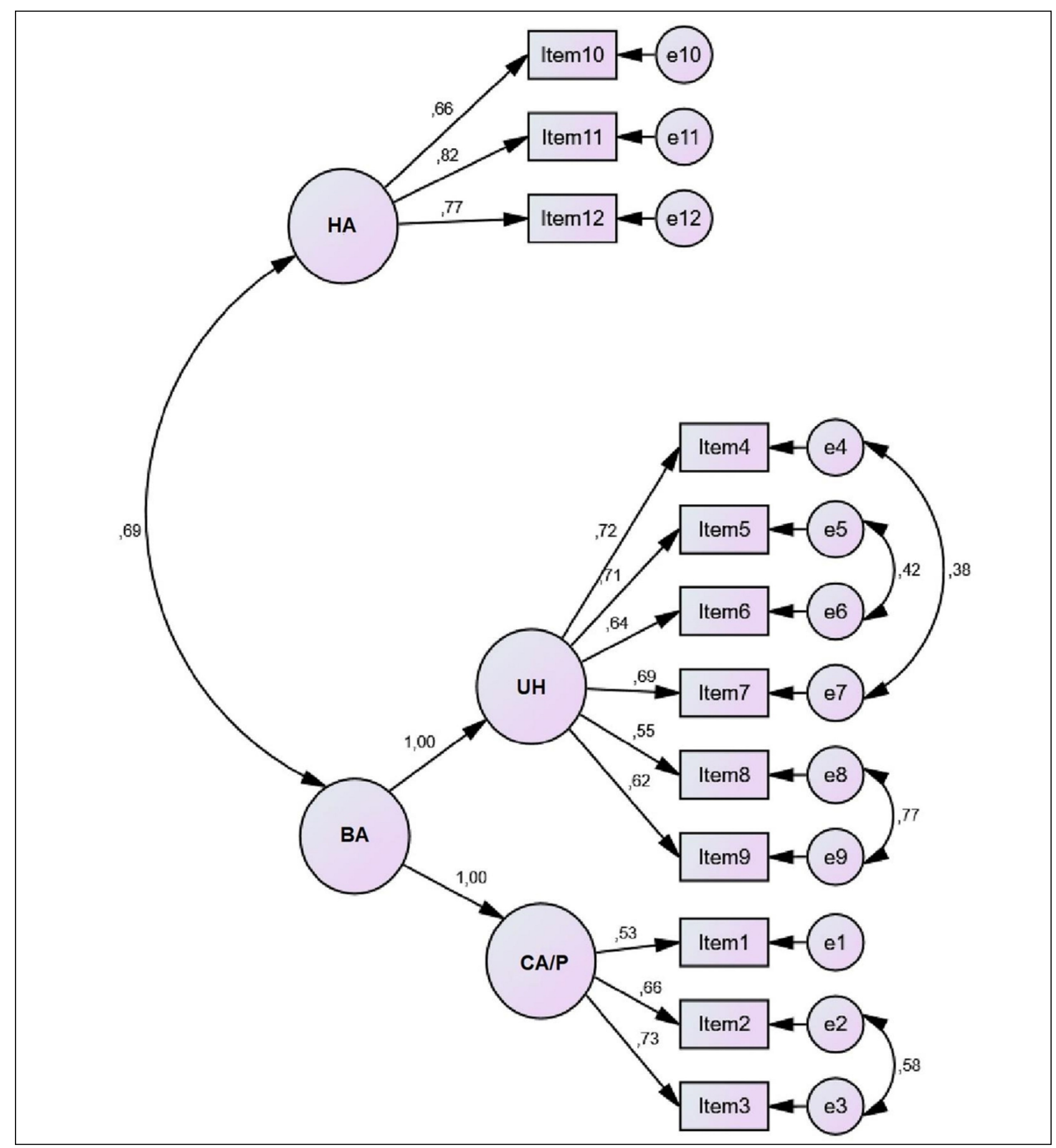

HA: Hostile ageism, BA: Benevolent ageism, UH: Unwanted help, CA/P: Cognitive assistance/protection 
between IA and HA was compared with the correlation coefficient between IA and BA using the interactive calculator developed by Lee and Preacher (26). The results showed that there was no significant difference between them $(z=.82, p>.05)$.

\section{Gender and Age Differences}

Gender and age group (young vs. old) differences for the mean values of $A A, H A, B A, C A / P, U H$ and IA were examined through correlation and indepen- dent t-test analyses. Age was negatively correlated only with CA/P (Table 2). To examine the age group differences, the sample was divided into two groups based on the sample's median age (30 years; young $\leq 30$ years; old $>30$ years). Results revealed no significant difference between age groups, whereas there was only one significant gender difference: $\mathrm{CA} / \mathrm{P}$ score for women was higher than for men, $t_{(220)}$ $=2.19, \mathrm{p}<.05$ (Table 3).

Table 2. Intercorrelations of study variables $(N=222)$

\begin{tabular}{|c|c|c|c|c|c|c|c|}
\hline & 1 & 2 & 3 & 4 & 5 & 6 & 7 \\
\hline Age (1) & - & -.06 & -.09 & $-.17^{\star \star}$ & -.03 & .03 & .01 \\
\hline Ambivalent ageism(AA) (2) & & - & $.93^{\star \star \star}$ & $.82^{* \star *}$ & $.92^{* * *}$ & $.74^{\star \star \star}$ & $.22^{* *}$ \\
\hline Benevolent ageism(BA) (3) & & & - & $.84^{* * *}$ & $.95^{* * *}$ & $.57^{\star \star *}$ & $.21^{\star \star}$ \\
\hline Cognitive assistance/protection(CA/P) (4) & & & & - & $.63^{* * *}$ & $.49^{\star \star \star *}$ & $.15^{\star}$ \\
\hline Unwanted help(UH) (5) & & & & & - & $.53^{\star \star *}$ & $.21^{\star *}$ \\
\hline Hostile ageism(HA) (6) & & & & & & - & $.16^{*}$ \\
\hline Implicit ageism(IA) (7) & & & & & & & - \\
\hline
\end{tabular}

${ }^{*} p<.05 ;{ }^{* *} p<.01 ; * * * 001$.

Table 3. Means and standard deviations of the AA, CA/P, UH, HA and the IAT scores for both gender and age ( $N=222)$

\begin{tabular}{|c|c|c|c|c|c|c|c|c|c|c|}
\hline & \multicolumn{5}{|c|}{ Gender } & \multicolumn{5}{|c|}{ Age } \\
\hline & \multicolumn{2}{|c|}{$\begin{array}{l}\text { Women } \\
(N=142) \\
\end{array}$} & \multicolumn{2}{|c|}{$\begin{array}{c}\text { Men } \\
(\mathrm{N}=80) \\
\end{array}$} & \multirow[b]{2}{*}{$t$} & \multicolumn{2}{|c|}{$\begin{array}{c}19-30 \text { years } \\
(\mathrm{N}=119)\end{array}$} & \multicolumn{2}{|c|}{$\begin{array}{c}31-69 \text { years } \\
(N=103)\end{array}$} & \multirow[b]{2}{*}{$t$} \\
\hline & M & SD & M & SD & & M & SD & M & SD & \\
\hline Ambivalent ageism (AA) & 3.76 & 1.24 & 3.57 & 1.13 & 1.10 & 3.73 & 1.20 & 3.64 & 1.21 & 0.55 \\
\hline Benevolent ageism (BA) & 3.95 & 1.34 & 3.63 & 1.23 & 1.74 & 3.90 & 1.31 & 3.75 & 1.31 & 0.82 \\
\hline $\begin{array}{l}\text { Cognitive assistance/ } \\
\text { protection (CA/P) }\end{array}$ & 3.43 & 1.58 & 2.96 & 1.44 & $2.19^{*}$ & 3.43 & 1.60 & 3.06 & 1.47 & 1.74 \\
\hline Unwanted help (UH) & 4.20 & 1.40 & 3.96 & 1.34 & 1.25 & 4.13 & 1.35 & 4.10 & 1.41 & 0.19 \\
\hline Hostile ageism (HA) & 3.19 & 1.36 & 3.40 & 1.30 & -1.12 & 3.24 & 1.36 & 3.31 & 1.32 & -0.42 \\
\hline Implicit ageism (IA) & 0.60 & 0.38 & 0.60 & 0.32 & -0.07 & 0.62 & 0.32 & 0.58 & 0.39 & 0.86 \\
\hline
\end{tabular}

Note. ${ }^{*} p<.05$ 


\section{DISCUSSION AND CONCLUSIONS}

Although another version of the AAS has recently been used for other purposes in Turkey (12), the present study is the first to report the psychometric qualities of a Turkish version of the scale in full detail and in relation to an implicit measure, namely the IAT. The study is a promising first step in the process of developing the Turkish version of AAS. The scores for AA, HA, BA, UH, CA/P and IA did not differ between genders and age groups, except for $\mathrm{CA} / \mathrm{P}$, suggesting that ageism may be a very common phenomenon across all individuals, as some social psychologists suggest (14). This finding is not consistent with the findings of two studies that did not employ implicit measures $(11,12)$; however, the general lack of significant differences in AA and IAT scores in relation to both gender and age is more plausible when the latent nature of both ambiva-

\section{REFERENCES}

1. United Nations, Department of Economic and Social Affairs, Population Division. World Population Ageing 2019 [e-book] UN Publication; 2019. [Internet]. Available from: https://www.un.org/en/development/desa/population/publications/pdf/ageing/ WorldPopulationAgeing2019-Highlights.pdf. Accessed: 27.06.2020.

2. Turkish Statistical Institute. Older People in Statistics, 2019. News Bulletin Number: 33712; 18 March 2020. [Internet]. Available from: https://data.tuik.gov.tr/ Bulten/Index?p=Elderly-Statistics-2019-33712. Accessed: 09.11.2020.

3. Löckenhoff CE, De Fruyt F, Terracciano A, et al. Perceptions of aging across 26 cultures and their culture-level associates. Psychol Aging 2009; 24(4): 941 54. (PMID: 20025408)

4. N, Raz. The Aging Brain: Structural Changes and Their Implications for Cognitive Aging, In: Roger A. Dixon, Lars Bäckman, Lars-Göran Nilsson (Eds). New Frontiers in Cognitive Aging. 1st edition, Oxford University Press, New York, USA 2004, pp 115-33.

5. Butler RN. Age-ism: Another form of bigotry. Gerontologist 1969; 9(4): 243-6. (PMID: 5366225).

6. North MS, Fiske ST. An inconvenienced youth? Ageism and its potential intergenerational roots. Psychol Bull 2012; 138(5): 982-97. (PMID: 22448913) lent and implicit forms of ageism are considered. In addition, unrepresentative nature of the present study's sample is somewhat compensated by the fact that the participants were recruited during the coronavirus disease pandemic, an unprecedented event that primed ageist attitudes in the minds of most people.

A final limitation of the present study is that, although AAS has been translated and used in Slovakia $(27,28)$, Poland (29) and India (30), a comparison of the psychometric qualities of Turkish version with those versions was not possible as detailed psychometric information regarding these applications were not reported in these studies.

We would like to thank Inquisit (Millisecond Software, Seattle, WA, USA) for providing free access to the IAT software during coronavirus disease pandemic.

7. Cary, LA, Chasteen AL, Remedios J. The ambivalent ageism scale: Developing and validating a scale to measure benevolent and hostile ageism. Gerontologist 2017; 57(2): e27-e36. (PMID: 27520730)

8. Cuddy AJC, Fiske ST, Glick P. The BIAS map: Behaviors from intergroup affect and stereotypes. J Pers Soc Psychol 2007;92 (4): 631-48. (PMID: 17469949)

9. North MS, Fiske ST. A prescriptive, intergenerational-tension ageism scale: Succession, identity, and consumption (SIC). Psychol Assess 2013; 25(3): 70613. (PMID: 23544391)

10. AL Chasteen, LA Carry, Age Stereotypes and Age Stigma: Connections to Research on Subjective Aging, In: M Diehl, H. W. Wahl (Eds). Annual Review of Gerontology and Geriatrics Subjective Aging: New Developments and Future Directions. 35th edition, Springer Publishing Co, USA 2014, pp 99-119.

11. Búgelová T, Chupková L, Kratochvílová L. Ageism at work across three generations. Cross-Cultural Studies: Education and Science 2019; 4(4): 97-106. (DOI: 10.24411/2470-1262-2019-10067).

12. Taşdemir N. Young group identification and motives as predictors of ageism, aging anxiety, and life satisfaction. J Genet Psychol 2020; 180(4): 1-16. (PMID: 32580665) 
13. Cangöz B, Altun A, Aşkar P, Baran Z, Mazman SG. Examining the visual screening patterns of emotional facial expressions with gender, age and lateralization. J Eye Mov Res 2013; 6(4): 1-15. (DOI:10.16910/ jemr.6.4.3).

14. Nosek BA, Banaji MR, Greenwald AG. Harvesting implicit group attitudes and beliefs from a demonstration web site. Group Dyn-Theor Res 2002; 6(1): 101-15. (DOI: 10.1037/1089-2699.6.1.101).

15. Greenwald AG, Banaji MR. Implicit social cognition: Attitudes, self-esteem, and stereotypes. Psychol Rev 1995; 102(1): 4-27. (PMID: 7878162)

16. Greenwald AG, McGhee DE, Schwartz JL. Measuring individual differences in implicit cognition: the implicit association test. J Pers Soc Psychol 1998; 74(6): 1464-80. (PMID: 9654756).

17. Greenwald AG, Banaji MR, Rudman LA, Farnham SD, Nosek BA, Mellott DS. A unified theory of implicit attitudes, stereotypes, self-esteem, and self-concept. Psychol Rev 2002; 109(1): 3-25. (PMID: 11863040).

18. Chopik WJ, Giasson HL. Age differences in explicit and implicit age attitudes across the life span. Gerontologist 2017; 57(S2): S169-S177. (PMID: 28854609).

19. Şimşek H, Bahadır H, Bilgin AC. Physicians' attitudes towards the elderly: Ageism in a university hospital in Turkey. Turkish Journal of Geriatrics 2019; 22(1): 101-11. (DOI: 10.31086/tjgeri.2019150579).

20. Köse $G$, Ayhan H, Taştan S, İyigün $E$, Hatipoğlu $S$, Açıkel $\mathrm{CH}$. Determination of the attitudes of students from different department in the field of health on the discrimination against the elders. Gülhane Med J 2015; 57(Suppl 2): 145-51. (in Turkish) (DOI: 10.5455/gulhane.152591).

21. Bulut $E$, Çilingir $D$. Attitudes of surgical nurses towards elderly. Turkish Journal of Geriatrics 2016; 19(4): 253-9.

22. Camcl, Y. (2015). The outgroup favoritism phenomenon in veiled and unveiled university students: An analysis of explicit and implicit attitudes via intergroup relations phenomenon. [Unpublished master's thesis, Bursa Uludag University, Bursa, Turkey]. (in Turkish). Available from: https://tez.yok.gov.tr/ UlusalTezMerkezi/giris.jsp. Accessed: 10.11.2020.

23. Özdemir, G. (2015). My achievements are not mine: Imposter phenomenon in light of the social identity, social dominance and system justification theories. [Unpublished master's thesis, Bursa Uludag University, Bursa, Turkey]. (in Turkish). Available from: https:// tez.yok.gov.tr/UlusalTezMerkezi/giris.jsp. Accessed: 10.11.2020

24. Alparslan K Kuşdil ME. (in press). Kürt üniversite öğrencilerinin kimlik yönetim stratejileri ve dış-grup tarafgirliğinin kimlikle ilgili eylem ve hedeflerle ilişkileri: Açık ve örtük ölçümlerle bir inceleme. Türk Psikoloji Dergisi.

25. Şenyurt AY Coşkun H Ünlü E S. Örtük çağrışım testi'ni Türkçe'ye uyarlama çalışması. OPUS Uluslararası Toplum Araştırmaları Dergisi-International Journal of Society Researches 2020; 15(26), 1-17. DOI: 10.26466/opus.632149. Available from: https:// dergipark.org.tr/tr/download/article-file/1133831. Accessed: 7.11.2020.

26. Lee IA, Preacher KJ. Calculation for the test of the difference between two dependent correlations with one variable in common [Computer software] 2013, September. [Internet] Available from: http://quantpsy.org/corrtest/corrtest2.htm Accessed: 27.06.2020.

27. Búgelová T, Chupková L, Kratochvílová L. Ageism at work across three generations. Cross-Cultural Studies: Education and Science 2019; 4 (4): 97-106. (DOI: 10.24411/2470-1262-2019-10067).

28. Čupková, L, Búgelová T, Fucsková Z. Attitudes towards the employment of seniors depending on the degree of ageism. Work and Organizational Psychology-2018 - Past, Present, and Challenges to The Future International Conference - Proceedings; Košice, Slovakia, 2019; 105-116. (ISBN 978-80-8152713-5) [Internet] Available from: https://unibook. upjs.sk/img/cms/2019/FF/psychologia-prace-a-organizacie-web.pdf. Accessed: 3.11.2020.

29. Daniel F, Massano I, Galhardo A, Barroso I. Ambivalent and hostile ageism. 27th European Congress of Psychiatry, Warsaw, Poland, 6-9 April 2019. [Internet] Available from: http://repositorio.ismt.pt/bitstream/123456789/1030/1/Poster\%20EPA19-Idadismo.pdf. Accessed: 3.11.2020.

30. Pramanik S, Biswal S. Ageism: A comparative study among young adults. IJARnD 2020; 5(5): 14-17. Available from: https://www.ijarnd.com/manuscripts/ v5i5/V5I5-1140.pdf. Accessed: 3.11.2020. 


\section{Appendix A}

Items of Turkish Version of AAS

1. Yaşlı insanlara bazı şeyleri yapmak için artık çok yaşıı olduklarını hatıllatmak iyi bir şeydir; yoksa sonunda başarısız olduklarında duyguları incinebilir.

2. Kendileri isteseler bile yaşlı insanların çalışmasına izin verilmemelidir; çünkü onlar topluma olan borçlarını çoktan ödemiş durumdadırlar.

3. Kendileri isteseler bile yaşlı insanların çalışmasına izin verilmemelidir; çünkü daha narin olduklarından kolayca hastalanabilirler.

4. Yaşlı insanlarla tane tane konuşmak iyidir; çünkü söyleneni anlamaları zaman alabilir.

5. Yaşılara kötü haber vermekten kaçınılmalıdır; çünkü kolayca duygulanıp ağlayabilirler.

6. Yaşlı insanları toplumun acı gerçeklerinden korumak gerekir; çünkü bunlardan çok etkilenebilirler.

7. Illk seferde hemen anlayamadıkları için, yaşıı insanlara bazı şeyleri tekrar tekrar anlatmak daha iyidir.

8. Kendileri istemese bile, yaşıı insanlara her zaman yardım teklif edilmelidir.

9. Kendileri istemese bile, yaşlı insanlara alışverişlerinde yardım edilmelidir.

10. Yaşlıların çoğu, aslında iyi niyetli söz ya da davranışları yaşlı insanlara yönelik bir hakaret ya da ayrımcılık olarak yorumlarlar.

11. Yaşlı insanlar çok alıngan olurlar.

12. Yaşlı insanlar iş yerlerinde yaşadıkları sorunları abartmayı pek severler. 


\section{Appendix B}

Items of English Version of AAS

1. It is good to tell old people that they are too old to do certain things; otherwise they might get their feelings hurt when they eventually fail.

2. Even if they want to, old people shouldn't be allowed to work because they have already paid their debt to society.

3. Even if they want to, old people shouldn't be allowed to work because they are fragile and may get sick.

4. It is good to speak slowly to old people because it may take them a while to understand things that are said to them.

5. People should shield older adults from sad news because they are easily moved to tears.

6. Older people need to be protected from the harsh realities of society.

7. It is helpful to repeat things to old people because they rarely understand the first time.

8. Even though they do not ask for help, older people should always be offered help.

9. Even if they do not ask for help, old people should be helped with their groceries.

10. Most old people interpret innocent remarks or acts as being ageist.

11. Old people are too easily offended.

12. Old people exaggerate the problems they have at work.

13. Old people are a drain on the health care system and the economy. ${ }^{\star}$ )

$\left.{ }^{*}{ }^{\star}\right)$ This item, with a factor load below 0.30 on CFA analysis, removed from the Turkish version of AAS. 